\title{
The Role of Folic Acid in Prevention of Neural Tube Defects Caused by High Dose Progesterone
}

\author{
Yüksek Doz Progesteronun Neden Olduğu NöralTüp Defekti Gelişiminde \\ Folik Asitin Önleyici Rolü
}

\author{
Iram IQBAL ${ }^{1}$, Khadija QAMAR ${ }^{1}$, Shadab Ahmad BUTT ${ }^{1}$, Omar HAYDER $^{2}$, Ifra SAEED ${ }^{1}$, Umbreen NOOR $^{1}$ \\ ${ }_{1}^{1}$ Army Medical College, Department of Anatomy, National University of Science and Technology, Islamabad, Pakistan \\ ${ }^{2}$ Rawalpindi Medical College, Academic Department of Obstetrics and Gynecology, Rawalpindi, Pakistan
}

Correspondence address: Iram IQBAL / E-mail: iramiqbal10@yahoo.com

\begin{abstract}
AIM: To describe the effect of high dose progesterone (HDP) alone, or in combination with folic acid (FA), on occurrence of neural tube defects (NTDs) in chick embryo.

MATERIAL and METHODS: 60 Fertile, specific eggs of Fyoumi species of chick were selected at zero hr of incubation. They were incubated at $37.5^{\circ} \mathrm{C}$ and $75 \%$ relative humidity until the embryos reached stage eight of development. At this stage the eggs were divided into four groups consisting of 15 eggs/group. The 1st group was incubated without any operation. The 2 nd group was injected with physiological saline. The $3 \mathrm{rd}$ and 4th groups were injected with HDP (20x physiologic dose of progesterone) and HDP with supplement of 5 micrograms/embryo of FA, respectively. After $48 \mathrm{hrs}$ of incubation, all embryos were reviewed for the presence of NTDs under light microscopy.

RESULTS: None of the eggs in the control, and saline injection groups showed NTDs, whereas $75 \%(9 / 12)$ of the embryos in the 3 rd group, and $58.3 \%(7 / 12)$ of the chick embryos in 4th group showed NTDs.
\end{abstract}

CONCLUSION: Exogenous progesterone at levels twenty times above its physiologic range in chick embryos causes NTDs. FA supplementation decreases the frequency of NTDs but does not abolish them.

KEYWORDS: Neural tube defects, Progesterone, Folic acid, Chick embryo, Neural tube closure

öz

AMAÇ: Yalnızca Progesteron ve progesterona ilave olarak Folik asit ile ile kombine edilmiş uygulamanın civciv embiryosunda nöral tüp defekti oluşumu üzerine olan etkisi.

YÖNTEM ve GEREÇ: Çalışmada, inkübasyonun 0. saatinde 60 fertil Fyoumi türü civciv embiryosu kullanıldı.Tüm embiryolar gelişimlerinin 8. evresine kadar, $37,5^{\circ} \mathrm{C}$ ve $75 \%$ nemli ortamda inkübasyona tabi tutuldu. Bu evrede embiryolar $15^{\prime}$ erli 4 gruba ayrıldı. Birinci grup herhangi bir işleme maruz bırakılmaksızın inkübasyona tabi tutuldu. İkinci gruba serum fizyolojik injeksiyonu yapıldı. Üçüncü gruba yüksek doz progesteron (fizyolojik dozun 20 katı), dördüncü gruba yüksek doz progesterona ek olarak 5 mikrogram folik asit injeksiyonu yapıldı. Bu işlemlerden sonraki 48 saat boyunca inkübe edilen embriyolar ışık mikroskobunda nöral tüp defekti gelişimi açısından incelemeye alındı.

BULGULAR: Kontrol grubunda ve serum fizyolojik injeksiyonu yapılan grupta nöral tüp defekti saptanmazken, 3. grupta \% 75 oranında (9/12), 4. grupta ise \% 58,3 (7/12) oranında nöral tüp defekti geliştiği görüldü.

SONUÇ: Fizyolojik dozun 20 katında uygulanan progesteron civciv embriyolarında nöral tüp defekti oluşumuna neden olmaktadır. Folik asit desteği nöral tüp defekti oluşum sıklığını azaltsa da defektin görülmesini tam olarak ortadan kaldıramamaktadır.

ANAHTAR SÖZCÜKLER: Nöral tüp defekti, Progesteron, Folik asit, Civciv embiryosu, Nöral tüp kapanması

\section{INTRODUCTION}

Progesterone, often called the pregnancy hormone, is a 21-carbon steroid hormone associated with pregnancy. A pregnant woman has approximately 10 times more progesterone in her blood, as compared with non-pregnant women, and its levels increase steadily during the entire pregnancy. Progesterone is produced by the corpus luteum in the ovaries and later on during the pregnancy, its level is maintained by the placenta. It is an essential hormone for the establishment and maintenance of pregnancy by inducing secretary changes in the lining of the uterus, which are important for implantation of the fertilized ovum (4).

Progesterone is also widely used in in-vitro fertilization (IVF) therapies (20). In IVF, the follicles are aspirated with a needle, removing many of the cells which would otherwise form the corpus luteum. It is adequate progesterone that prevents the shedding of uterine lining and if its level is not enough at the time when embryos have been put back can lead to failure of IVF cycle. Thus, since the early days of IVF, progesterone supplementation has been used to make up for the deficit 
created by removal of these cells (14). In this context, progesterone is usually prescribed starting at the latter part of the menstrual cycle and continuing on to $8^{\text {th }}-10^{\text {th }}$ weeks of the pregnancy.

Babies born through IVF are up to $4 \%$ more likely to suffer from birth defects that range from relatively minor problems like cleft palate to severe ones such as spina bifida (6). The cause of the defects is not certain; however, possible explanations include the methodology of the procedure itself, how the egg, sperm or embryo are manipulated, or the medications that are given to induce ovulation or to sustain pregnancy (6).

Around the world, there are hundreds of thousands of pregnancies affected each year by an NTD, with some fetal demise through spontaneous or induced losses. Seven percent of infant deaths from birth defects are a result of NTDs. Based on animal studies, epidemiologic studies and intervention trials, maternal folic acid (vitamin B9) is known to be protective for neural tube defects (NTD), primarily spina bifida and anencephalus (8).

The present study was designed to describe the role of folic acid in the prevention of neural tube development defects caused by high dose progesterone. The hypothesis under consideration was that folic acid prevents the neural tube defect caused by high dose progesterone.

\section{MATERIAL and METHODS}

The study design of this project was experimental. The study protocol was reviewed and approved by the Institutional Ethics Review Committee of Army Medical College, Rawalpindi. Chick embryos were exposed to N/S, HDP, and HDP with FA supplement, and compared with controls to see the effect of HDP on NTDs and also to analyse the role of FA in prevention of NTDs caused by HDP. The project was carried out at the Poultry Research Institute, Rawalpindi. The study was done on four main groups.

Control Group A: G 1

Control Group B: $\mathrm{G} 2$

Experimental Group A: G 3

Experimental Group B: G 4

\section{Description of chick embryos}

Fertile, specific pathogen free eggs of Fyoumi species of chick were selected and obtained from Poultry Research Institute Punjab, Rawalpindi at zero hour of incubation. The eggs were incubated at $37.5^{\circ} \mathrm{C}$ and $75 \%$ relative humidity until the embryos reached stage eight of development according to Hamburger and Hamilton (7). At this stage the eggs were labelled and divided into four groups consisting of 15 eggs per group. These groups were:

$\mathrm{G}$ 1, uninjected eggs;

$\mathrm{G} 2$, injected with $\mathrm{N} / \mathrm{S}$

$\mathrm{G}$ 3, injected with HDP

G 4, injected with HDP with FA supplement

\section{Dosage of progesterone}

The normal progesterone level that a chick embryo is exposed to is found to be $0.823 \pm 0.035$ nanogram $/ \mathrm{ml}$ (18). The calculated dose of progesterone, 157 nanograms, (Water Soluble Progesterone, Sigma - Aldrich Comp. code: P7556, St. Louis, Missouri, USA) was diluted in $0.1 \mathrm{ml}$ of physiological saline $(0.9 \% \mathrm{NaCl})$ for $\mathrm{G} 3$. G4 was injected with progesterone 157 nanograms diluted in $0.1 \mathrm{ml}$ of physiological saline $(0.9 \%$ $\mathrm{NaCl}$ ) along with supplement of 5 micrograms/embryo folic acid (13).

\section{Method of injection}

At stage eight of development, (26 to $29 \mathrm{hrs}$ ) the eggs from G2, G3, and G4 were washed with $70 \%$ alcohol and properly labelled on the outer shell. A hole was made on the blunt pole of the eggs with a sharp and thick needle under laminar flow. Using a sterile 28-gauge needle and a tuberculin syringe, $0.1 \mathrm{ml}$ of the fluid was injected from the blunt end under the embryonic disc. The holes were sealed with paraffin. The eggs were then being placed again in the hatchery.

\section{Embryo collection}

The eggs were opened at 48 hours of incubation. The eggs were cracked open and the outer shells were chipped out to create a large opening to see the embryo. The viability of the embryos was assessed by the heartbeat. The embryos were transferred to a Petri dish by careful dissection along the allantoic stalk and other embryonic structures. All the embryos were fixed with Carnoy's fluid and were stained with $\mathrm{HCl}$-carmine and examined under stereomicroscope to assess any gross developmental abnormalities. Then, embryos which were passed Hamburger Hamilton stage 12 were embedded into paraffin and seven microns thick paraffin sections were cut for light microscopic examination.

\section{RESULTS}

\section{Quantitative Observations}

After 48 hours of incubation when embryos were examined directly under dissecting microscope, and as whole mount and transverse section under light microscope, it was observed that in controlled groups G1 and G2, the neural tube was closed in all live embryos (Figure 1, 2). However, 9/12 (75\%) of the live embryos in G3 (Figure 3,4) and 7/12 (58.3\%) of the live embryos in G4 (Figure 5,6 ) had an open neural tube (Table I). There was defect in the closure of neural tube mostly in the region of lumbosacral region (Figure 3, 5).

\section{Qualitative Observations}

Treatment of embryos with HDP resulted in a high percentage of embryos exhibiting non-closure-type neural tube defect.

Examination of defective regions of the embryos directly under dissecting microscope and as whole mount and transverse section under light microscope revealed that the neural folds usually elevated normally, but convergence often failed to occur (Figure 3,6). In many of the embryos 
with neural tube defects, the elevated neural folds actually diverged, flaring laterally (Figure 4,5). The formation of neural tube defects in embryos treated with HDP were principally due to a failure of the elevated neural folds to converge

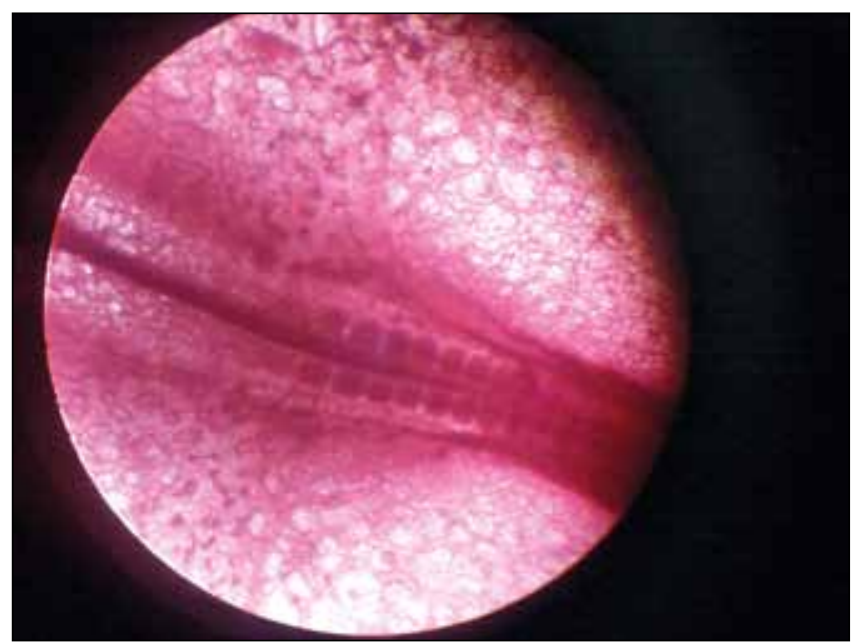

Figure 1: Examination of 48 hours embryo of control group, under dissecting microscope. Embryo is fully developed according to its stage of development. Neural tube is closed throughout its length.

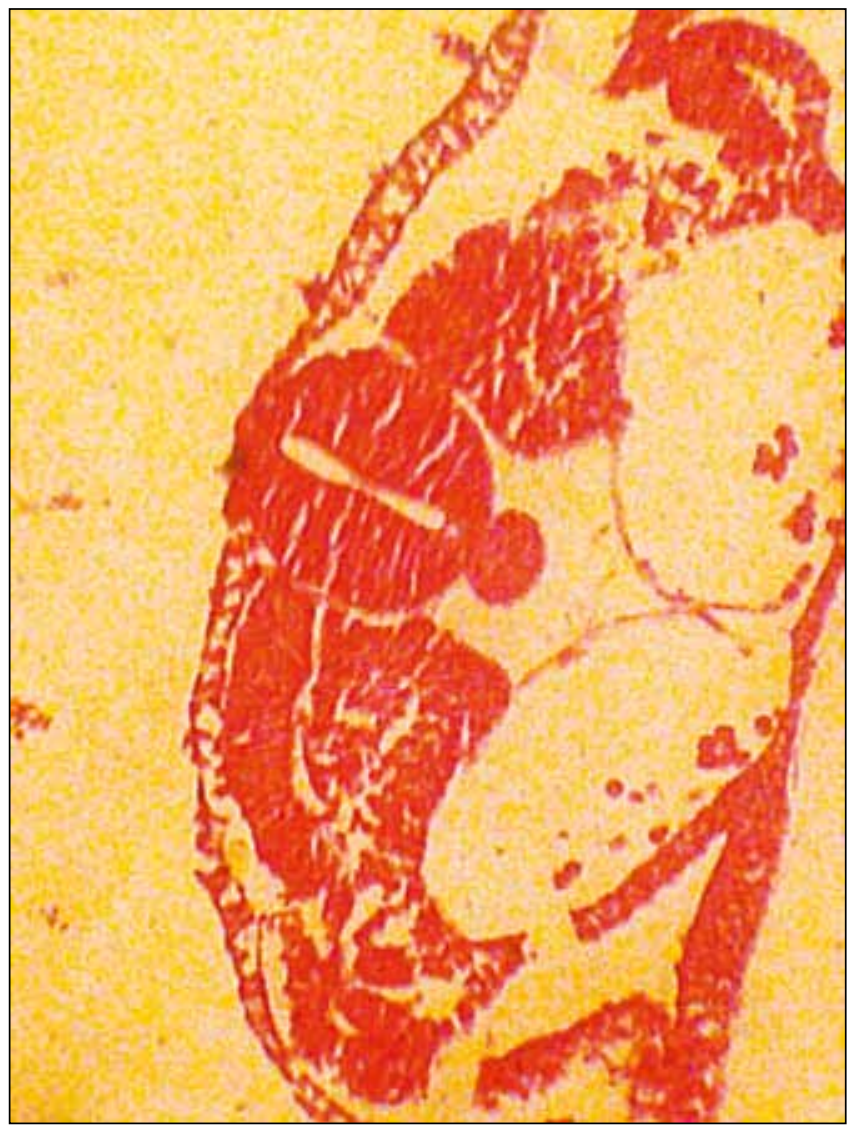

Figure 2: Transverse section through the spinal cord region of a control embryo. The neural tube is closed. toward the dorsal midline. Fusion occasionally failed to occur at various levels along the length of the spinal cord, but much more frequently fusion was inhibited only in the area of the posterior neuropore (Figure 3, 5).

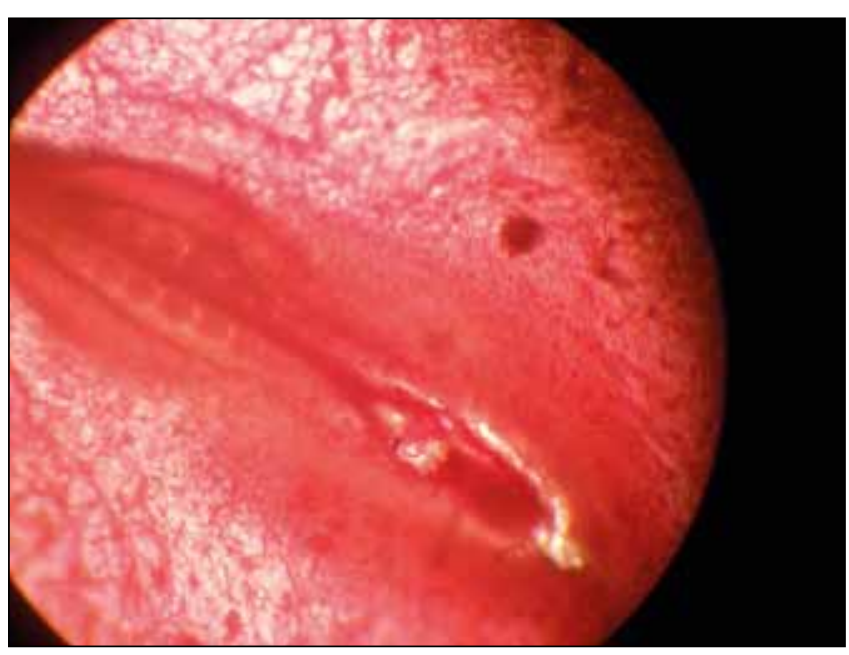

Figure 3: Examination of 48 hours embryo of experimental group three (G3), under dissecting microscope. Embryo is fully developed according to its stage of development. Neural tube is opened in the lumbosacral region.

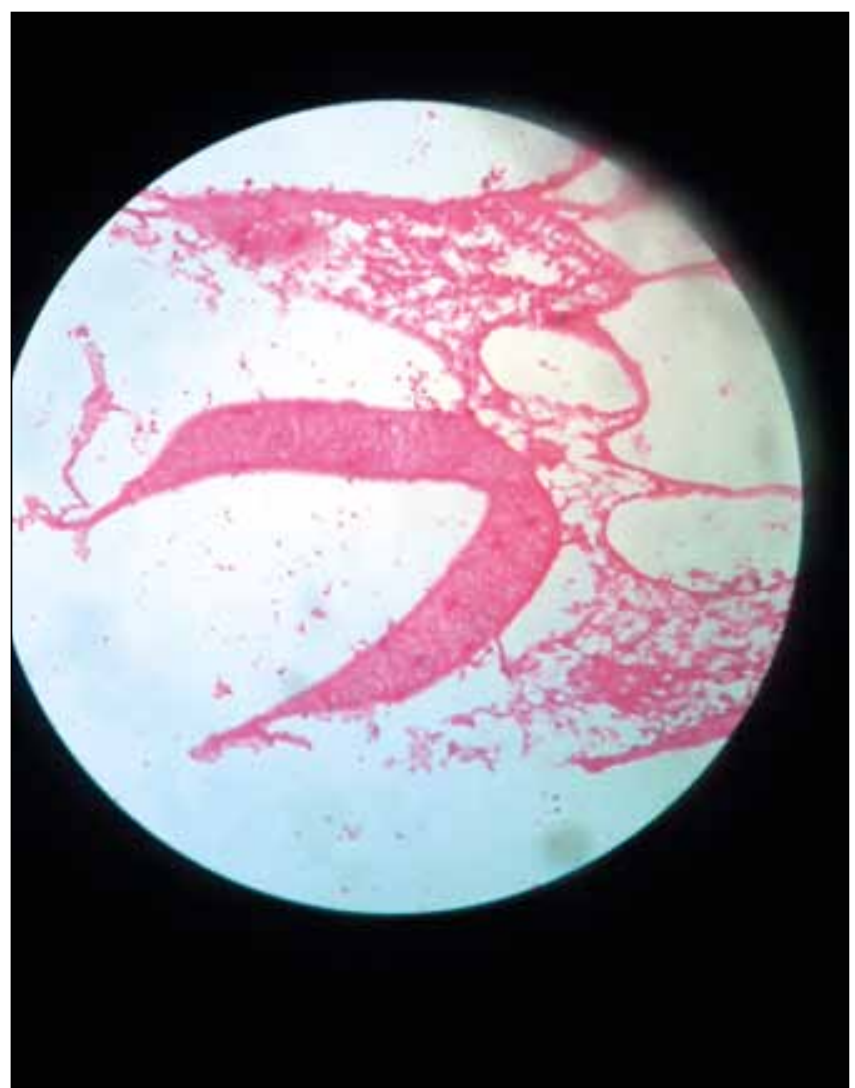

Figure 4: Transverse section of 48 hours embryo of experimental group three (G3), under light microscope - Open neural tube. 
Table I: Total Number of Embryos with or without NTD in Control Groups (G1 \& G2) and Experimental Groups (G3 \& G4) after 48 Hours of Incubation

\begin{tabular}{|c|c|c|c|}
\hline \multirow{2}{*}{ Groups } & \multicolumn{3}{|c|}{ Number of embryos } \\
\cline { 2 - 4 } & Live Embryos & With NTD & Without NTD \\
\hline G1 & 13 & $0(0 \%)$ & $13(100 \%)$ \\
G2 & 12 & $0(0 \%)$ & $12(100 \%)$ \\
G3 & 12 & $9(75 \%)$ & $3(25 \%)$ \\
G4 & 12 & $7(58.3 \%)$ & $5(41.7 \%)$ \\
\hline
\end{tabular}

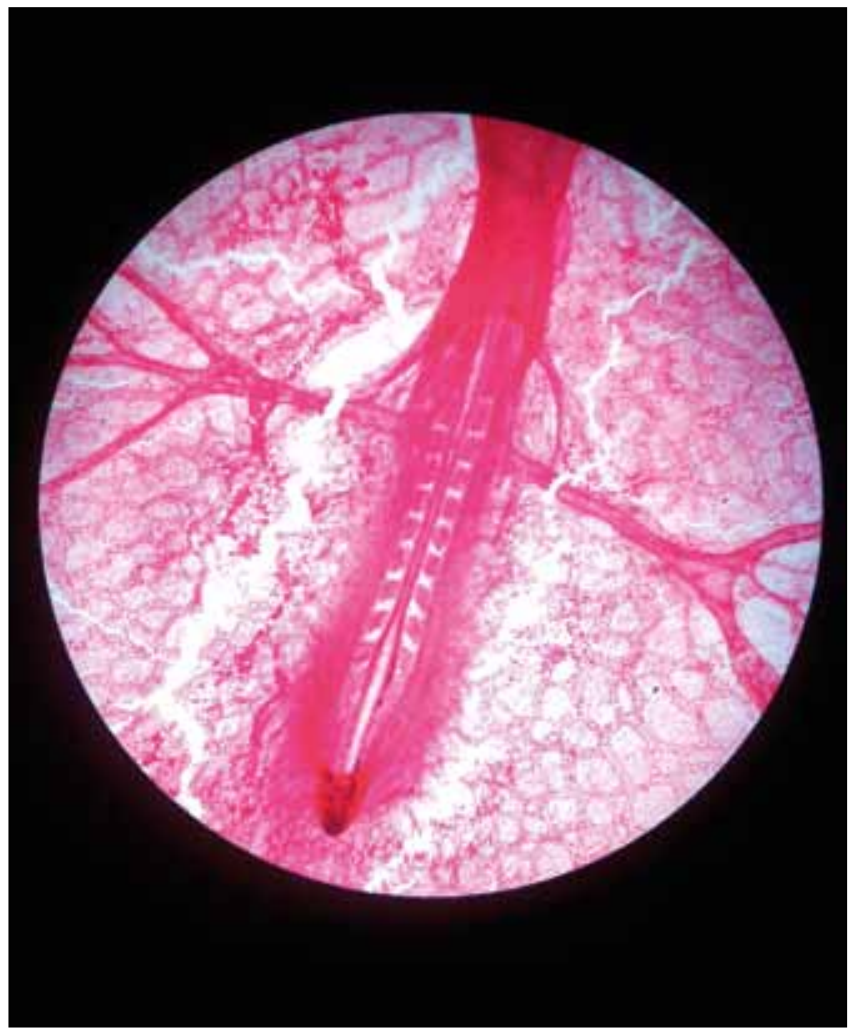

Figure 5: Whole mount of 48 hours embryo of experimental group four (G4), under light microscope. Embryo is fully developed according to its stage of development. Neural tube is opened in the lumbosacral region.

\section{DISCUSSION}

The major finding of this study is that in chick embryos exposed to high dose progesterone, supplementation with folic acid reduces, but does not obviate the incidence of neural tube defects.

High dose extraneous progesterone is a known teratogen in certain animal models. In rabbit embryos, when progesterone is introduced at the appropriate time of embryonic development, neural tube defects result frequently (1). Mice and rats do not show such defects. In chick embryos, exposure to high dose, natural progesterone has been shown to cause neural tube defects (18). In human embryos, use of natural progesterone is practiced frequently in threatened abortion, luteal phase defect and as part of in-vitro fertilization (IVF)

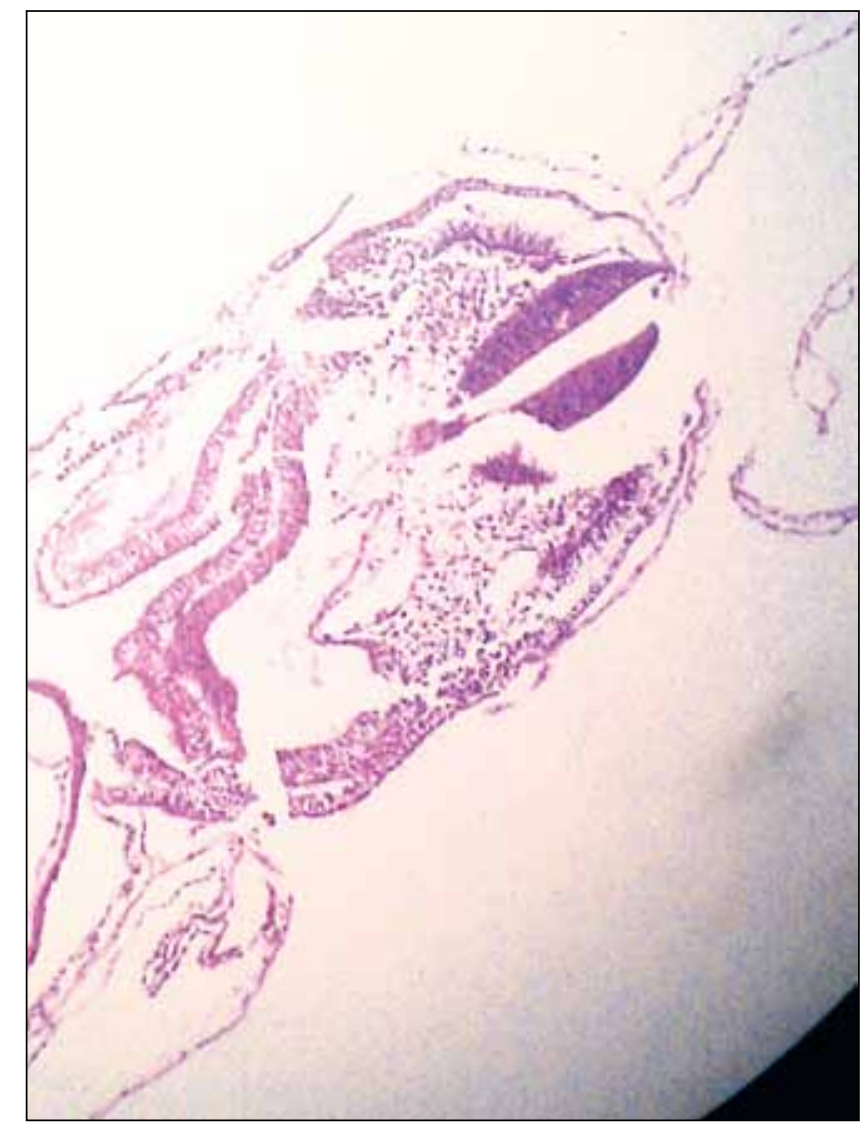

Figure 6: Transverse section of 48 hours embryo of experimental group four (G4), under light microscope - Open neural tube.

therapy. The use is primarily intended to supplement the endogenous production of progesterone by the corpus luteum, and later the placenta, during pregnancy. IVF and Intra cytoplasmic sperm injection (ICSI) is the clinical context in which natural, exogenous progesterone is administered during the period of organogenesis of the embryo. Thus, the findings of the present study are particularly relevant to IVF and ICSI, which is being performed with increasing popularity all around the world. Theoretically, the dosage of exogenous progesterone administered during in-vitro fertilization should be small, as it is intended to make up for the iatrogenically induced deficiency of endogenous progesterone caused by the use of $\mathrm{GnRH}$ agonists or antagonists during the procedure of IVF. International guidelines state a maximum daily dose of $600 \mathrm{mg}$ progesterone as vaginal gel or pessaries, 
or $100 \mathrm{mg}$ intramuscular (20)and the average serum levels of progesterone achieved at this dose would be around 50-60 $\mathrm{ng} / \mathrm{ml}$ (19) however, anecdotal evidence from Pakistani IVF specialists suggests that in clinical practice, the doses have been known to go up to $1600 \mathrm{mg}$ daily (in case of multiple pregnancies), and plasma levels reaching over $250 \mathrm{ng} / \mathrm{ml}$ seven to thirty times the normal range of $9-45 \mathrm{ng} / \mathrm{ml}$ in first trimester (personal communication with IVF specialists in Pakistan). Serum levels this high correspond to the 20 times physiological levels of progesterone that was introduced in the present experiment.

Although a large number of studies have failed to show progesterone as a human teratogen $(10,12,21)$. It would be pertinent to note that almost all of the major studies performed to explore the link of exogenous progesterone with birth defects were carried out in the 1970s and 1980s, when in-vitro fertilization was not as common as it is now being the mechanism of conception in almost $1 \%$ of all live births in developed countries. All of the studies were casecontrol, and suffer from biases relating to recall of information relating to the initial part of the pregnancy, when actual questioning occurred almost 9 months later, after the delivery of the baby. None of the studies explored a dose-response relationship with high dose progesterone administered in the period of organogenesis. Finally, IVF, the only large scale use of natural progesterone in the teratogenically relevant period of pregnancy, has been shown to increases the risk of neural tube defects (9). Whether it is due to the use of exogenous progesterone or not is not known, but, the discussion on the role of progesterone in occurrence of neural tube defects during IVF is far from conclusive.

Folic acid supplementation during pregnancy is routine, considering its proven benefits on reduction of neural tube defects in the fetus (2). Although folate supplementation has reduced the incidence of neural tube defects by $70 \%$ (5), as the present study found, it will reduce by not completely abolish neural tube defects caused due to exposure to exogenous progesterone. Modification of activity on GABA-A receptor in neural embryonal neural tissue is the key to understanding the effects of progesterone and the decrease in frequency of progesterone induced neural tube defects by folic acid, as noted in the present study. GABA-A receptor agonists increase the frequency of neural tube defects, especially spina bifida (3); the anti-epileptic drug Valproic acid, which is notorious for its teratogenic effects, and has important effects on the GABA-A receptor, may act through this pathway $(3,16)$. Progesterone acts as an agonist at GABA-A receptors (16). Folic acid itself has been shown to reduce GABAergic action at GABA-A receptors by its interaction with this receptor complex (22). In reduction of neural tube defects induced by high dose progesterone, the role of folic acid is probably different from its actions in prevention of neural tube defects not induced by high dose progesterone, which are postulated to be due to its effects on homocystiene and methionine metabolism(15). In view of the aforementioned data, it is hypothesized that folic acid may act as an antagonist at GABA-A receptor complex, and thus reduce the binding, and thus the agonistic effects of high dose progesterone on GABA-A receptors. It would be pertinent to test this hypothesis in future experimental studies, and to seek a dose-response relationship between folic acid and progesterone supplementation on GABAreceptors and neural tube development, that would be of clinical use to women undergoing IVF treatment. Another study done by Elisa et al. show that progesterone, a sterol produced by the placenta, inhibits both FA uptake and efflux in BeWo cells and primary cultured human trophoblasts (11), in view of this study it can be considered that HDP might be responsible for NTDS by acting on trophoblast, inhibiting folic acid uptake and then producing its deficiency. Further studies are needed to prove this effect and to study whether these NTD could be prevented by increasing the dose of folic acid.

There are multiple unanswered questions in relation to this study that can be addressed in future research work. It is not conclusively known whether the increased risk of neural tube defects in babies born through IVF is related to progesterone. Progesterone dosage regimens in IVF are non-standardized and multiple additional factors such as absorption and metabolism of various dosing forms used in IVF need to be evaluated in detail. Large, follow-up studies on babies born through IVF would be able to settle this question in future research.

Further research is required to highlight the interaction of progesterone and folic acid on embryonic neural tissue and to explore whether a dose-response mechanism exists. Only then, definite recommendations can be made on the need for reduction of use of progesterone, or preferential use of a specific preparation or route, or supplementation that would decrease the risk for neural tube defects caused by progesterone in babies born through IVF.

In conclusion, the present study found that exposure to high dose progesterone greatly increases the incidence of neural tube defects in chick embryos. Concurrent supplementation with folic acid decreased the incidence of the defects, but did not obviate them. Further research is required to explore the relationship between natural progesterone and neural tube defects in humans.

\section{REFERENCES}

1. Andrew FD, Staples RE: Prenatal toxicity of medroxyprogesterone acetate in rabbits, rats and mice. Teratology 15: 25-32, 1977

2. Au KS, Ashley-Koch A, Northrup H: Epidemiologic and genetic aspects of spina bifida and other neural tube defects. Dev Disabil Res Rev 16(1): 6-15, 2010

3. Briner $W$ : The effect of GABA receptor ligands in experimental spina bifida occulta. BMC Pharmacol 1: 2, 2001

4. Cunningham FG (ed): Physiology of pregnancy. William's Obstetrics. 21st ed. New York: McGraw-Hill, 2001

5. Fleming A, Copp AJ: Embryonic folate metabolism and mouse neural tube defects. Science 280(5372): 2107-2109,1998 
6. Halliday J: Outcomes of IVF conceptions: Are they different? Best Pract Res Clin Obstet Gynaecol 21(1): 67-81, 2007

7. Hamburger $\mathrm{V}$, Hamilton $\mathrm{HL}$ : A series of normal stages in the development of the chick embryo. Dev Dyn 195: 231-272, 1992

8. Jaquier M: Prevention of anencephaly. [article on the internet] (c) 2010 [Updated 2007 Oct 11; Cited 2010 Oct 15]. Available from: http: //www.anencephalie-info.org/e/prevention.php

9. Källén B, Finnström $O$, Lindam A, Nilsson $E$, Nygren KG, Otterblad PO: Congenital malformations in infants born after in vitro fertilization in Sweden: Birth defects. Res A Clin Mol Teratol 88(3): 137-144, 2010

10. Katz Z, Lancet M, Skornik J, Chemke J, Mogilner BM, Klinberg $M$ : Teratogenicity of progestogens given during the first trimester of pregnancy. Obstet Gynecol 65: 775-780,1985

11. Keating E, Gonçalves P, Lemos C, Costa F, Campos I, Smith SB, Bridges CC, Martel F: Progesterone inhibits folic acid transport in human trophoblasts. J Membr Biol 216(2-3):143-152, 2007

12. Kimmel GL, Hartwell BS, Andrew FD: A potential mechanism in medroxyprogesterone acetate teratogenesis. Teratology 19: 171-176, 1979

13. Li Y, Li Z, Chen X, Qi P: Homocysteine-induced neural tube defects in chick embryos and protection of folic acid. Wei Sheng Yan Jiu 27(6): 372-376,1998

14. Massey JB: IVF and Progesterone Treatment. [article on the internet] () 2010 [Updated 2010 Feb 10; Cited 2010 Oct 15]. Available from: http: //cnyfertility.com/2010/02/02/ivf-andprogesterone-treatment/
15. Morrell MJ: Folic Acid and epilepsy. Epilepsy Curr 2(2): 31-34, 2002

16. Ochua JG: Antiepileptic drugs. [monograph on the internet]. Jacksonville, FL: Medscape Inc.; @) 1994-2010 [Updated 2009 Apr 17; Cited 2010, Oct 10]. Available from: http: //emedicine. medscape.com/article/1187334

17. Paczoska-Eliasiewicz HE, Gertler A, Proszkowiec M, Proudman J, Hrabia A, Sechman A, Mika M, Jacek T, Cassy S, Raver N, Rzasa J: Attenuation by leptin of the effects of fasting on ovarian function in hens (Gallus domesticus). Reproduction 126: 739-751, 2003

18. Pamir E, Ali D, Ismail C, Sanli E, Ali K, Mustafa T: The effects of high dose progesterone on neural tube development in early chick embryos. Neurol India 54(2): 178-181, 2006

19. Penzias AS, Alper MM: Luteal support with vaginal micronized progesterone gel in assisted reproduction. Reprod Biomed Online 6: 287-295, 2003

20. Pritts EA, Atwood AK: Luteal phase support in infertility treatment: A meta-analysis of the randomized trials. Hum Reprod 17: 2287-2299, 2002

21. Rothman KJ, Fyler DC, Goldblatt A, Kreidberg MB : Exogenous hormones and other drug exposures of children with congenital heart disease. Am J Epidemiol 109: 433-439,1979

22. Van Rijn CM, Willems-van Bree $E$, Dirksen $R$, Rodrigues de Miranda JF: The GABAA receptor complex in relation to epilepsy. Reversal of $[3 \mathrm{H}] \mathrm{TBOB}$ inhibition: A prediction of proconvulsive properties? Epilepsy Res 12(2):163-170, 1992 